\title{
First report of Panicum mosaic virus in buffalo grass (Stenotaphrum secundatum) from Australia
}

\author{
John E. Thomas • Visnja Steele
}

Received: 15 December 2010/Accepted: 10 March 2011/Published online: 1 April 2011

(C) Australasian Plant Pathology Society Inc. 2011

\begin{abstract}
Panicum mosaic virus (PMV) was identified from Stenotaphrum secundatum (buffalo grass or St Augustine grass) showing leaf mosaic symptoms, from New South Wales. The isometric virions were decorated by antibodies to PMV by immunosorbent electron microscopy. The coat protein gene was $85 \%$ and $90 \%$ identical, at the nucleotide and amino acid levels, respectively, to the published sequence of PMV. This represents the first record for PMV for Australia, and the first outside North America.
\end{abstract}

Keywords Panicovirus · Nucleotide sequence $\cdot$ Coat protein

Stenotaphrum secundatum (buffalo grass or St Augustine grass) is a hard wearing and vigorous warm season lawn grass, thought to be endemic to the Atlantic coasts of the Americas and Africa (Sauer 1972). In the USA and Mexico it can be affected by St Augustine decline disease, caused by Panicum mosaic virus (PMV). This disease is characterised by leaf mosaic symptoms, and sometimes necrosis of the leaves and stolons which can lead to rapid degeneration of the turf (Cabrera and Scholthof 1999). PMV was first recorded from Kansas in 1953 on Panicum virgatum (Sill and Pickett

J. E. Thomas

Centre for Plant Science, Queensland Alliance for Agriculture and Food Innovation, The University of Queensland,

Brisbane, QLD, Australia

\section{Steele}

Agri-Science Queensland, a service of Department of Employment, Economic Development and Innovation, Horticulture and Forestry Science,

Brisbane, QLD, Australia

\section{J. E. Thomas $(\bowtie) \cdot$ V. Steele}

Ecosciences Precinct,

GPO Box 46 Brisbane, QLD 4001, Australia

e-mail: john.thomas@deedi.qld.gov.au
1957), and later on S. secundatum (McCoy et al. 1969) and Eremochloa ophiuroides (Haygood and Barnett 1992). The known distribution is confined to the southern USA and Mexico (Cabrera and Scholthof 1999). PMV is the type member of the genus Panicovirus (family Tombusviridae). It has a monopartite, single stranded positive sense RNA genome contained within $25-30 \mathrm{~nm}$ isometric virions (Büchen-Osmond 2006) and can also support the replication of its satellite RNAs (satRNAs) and/or Panicum mosaic satellite virus (PMSV) (Buzen et al. 1984; Cabrera and Scholthof 1999).

In June 2008, a sample of S. secundatum cv. Palmetto with leaf mosaic symptoms (isolate 2349, Fig. 1) was received from a commercial turf farm in the Hawkesbury basin area, New South Wales. Isometric virions 25-30 nm in diameter (Fig. 2) were observed by electron microscopy of a sap preparation, negatively contrasted with $1 \%$ ammonium molybdate $\mathrm{pH} 6.8$, and these particles were specifically decorated with antiserum to the St Augustine decline strain of PMV (supplied by C. Niblett) by immunosorbent electron microscopy (ISEM) using the method of Thomas (1986). Isometric particles (17 $\mathrm{nm}$ diameter) indicative of PMSV were not observed in the sap preparation.

Total RNA was extracted from the leaves of the virusinfected sample using the Biosprint 15 RNA Plant Kit (Qiagen, Hamburg, Germany), and cDNA was prepared using Superscript III and primer PMV ext R (see below), both according to the manufacturers' instructions. PCR primers PMV CP ext F (5' CAGTGGTGGTTCCCTCATAC $3^{\prime}$ ) and PMV ext R (5' TGCTGTACGGTCTGTCTCAAA 3') were designed using the Primer 3 software package (http://www. simgene.com/Primer3), based on the only published genome sequence of PMV available, a USA isolate (GenBank NC_002598). These primers allowed the amplification of the complete coat protein (CP) gene and short flanking 

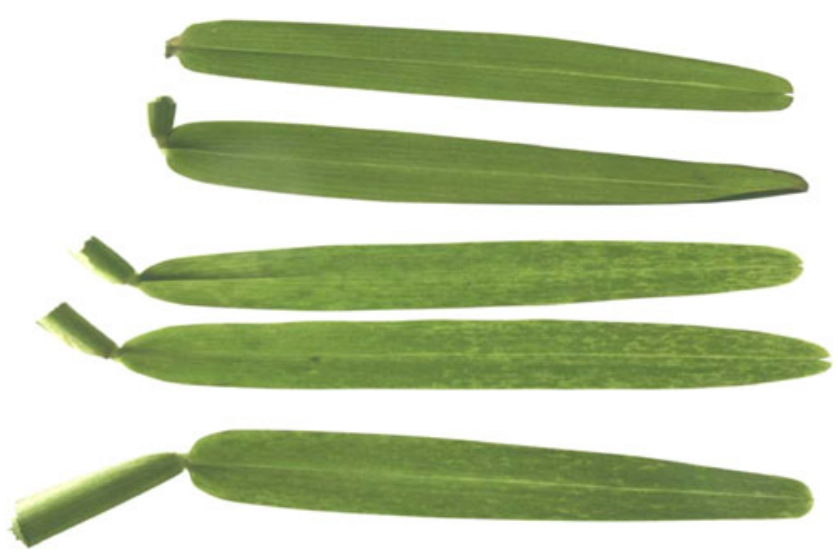

Fig. 1 Stenotaphrum secundatum (buffalo grass) infected with PMV and displaying mosaic symptoms (lower three leaves, cv. Palmetto) compared with uninfected leaves (upper two leaves, cv. Sir Walter)

sequences, with a predicted amplicon size of $921 \mathrm{bp}$. The $25 \mu \mathrm{L}$ PCR reaction mix contained $1 \times$ PCR buffer (Qiagen), $1 \mu \mathrm{L}$ cDNA template, $1.8 \mathrm{mM} \mathrm{MgCl} 2,5$ nmoles dNTPs, 10 pmoles of each primer and $1 \mathrm{U}$ Taq polymerase (Qiagen, Cat. No.201203). PCR cycling parameters were an initial denaturation at $94^{\circ} \mathrm{C} / 1 \mathrm{~min}$, followed by 35 cycles of $94^{\circ} \mathrm{C} /$ $20 \mathrm{~s}, 58^{\circ} \mathrm{C} / 30 \mathrm{~s}, 72^{\circ} \mathrm{C} / 1 \mathrm{~min}$, and a final extension of $72^{\circ} \mathrm{C} /$ $3 \mathrm{~min}$. The PCR products were electrophoresed on a $1 \%$ agarose gel and stained with ethidium bromide. The expected $921 \mathrm{bp}$ amplicon was excised from the agarose gel using a QIAEX 11 Gel Extraction Kit (Qiagen) and cloned using a TOPO TA Cloning Kit for Sequencing (pCR 4 TOPO Vector) (Invitrogen). Clones were selected on the basis of insert size and were sequenced at the Australian Genome Research Facility, University of Queensland. Four clones

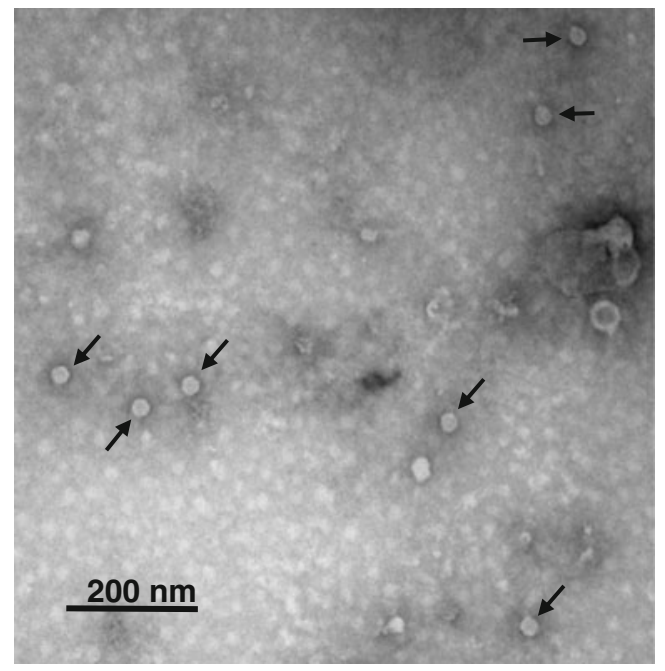

Fig. 2 Virions of PMV isolate 2349 (arrows), from a sap preparation from Stenotaphrum secundatum, negatively contrasted with $1 \%$ ammonium molybdate. Bar represents $200 \mathrm{~nm}$ were sequenced in both directions, and three had identical sequences, the fourth differed by a single nucleotide in a redundant position. The consensus sequence was $85 \%$ and $90 \%$ identical to the published PMV CP sequence (GenBank NC_002598) at the nucleotide and amino acid levels, respectively.

Previous characterisation of PMV has indicated the existence of at least six serotypes of the virus (Buzen et al. 1984), but as only two sequences of PMV are now available on GenBank for comparison, the extent of sequence variation between these serotypes is not known. On the basis of the high sequence identity with PMV and the strong serological cross reaction in ISEM, isolate 2349 is considered to be an isolate of PMV.

No biological vector is known for PMV, but it is readily spread vegetatively in stolons or in turf and through mechanical transmission e.g. lawn mowing (Niblett and Toler 1977). New cultivars of buffalo turf grass are gaining popularity in Australia, and it is likely that PMV will become more widespread as infected vegetative material of cv Palmetto is spread within the turf industry. However, the risk to Australian agriculture from this virus appears to be minimal, as there are no records in the literature of natural infections of PMV in crop plants in the Poaceae.

PMV-2349 has been lodged in the plant virus collection of the Agri-Science Queensland (formerly Queensland Primary Industries and Fisheries) Herbarium Brisbane, Qld (code BRIP 53087 a) and the nucleotide sequence in GenBank with accession code HM017843.

\section{References}

Büchen-Osmond C (ed) (2006) Index to ICTVdB virus descriptions. In: ICTVdB - The Universal Virus Database, version 4. ICTVdB Management, Mailman School of Public Health, Columbia University, New York, NY, USA

Buzen FG Jr, Niblett CL, Hopper GR, Hubbard J, Newman MA (1984) Further characterization of Panicum mosaic virus and its associated satellite virus. Phytopathology 74:313-318

Cabrera O, Scholthof K-BG (1999) The complex viral etiology of St. Augustine decline. Plant Dis 83:902-904

Haygood RA, Barnett OW (1992) Widespread occurrence of centipedegrass mosaic in South Carolina. Plant Dis 76:4649

McCoy NL, Toler RW, Amador J (1969) St. Augustine decline (SAD) - a virus disease of St. Augustine grass. Plant Dis Rep 53:955-958

Niblett CL, Toler RW (1977) Panicum mosaic virus. CMI/AAB Descriptions of Plant Viruses No. 177

Sauer JD (1972) Revision of Stenotaphrum (Gramineae: Paniceae) with attention to its historical geography. Brittonia 24:202222

Sill WH, Pickett RC (1957) A new virus disease of switchgrass, Panicum virgatum L. Plant Dis Rep 41:241-249

Thomas JE (1986) Purification and properties of ginger chlorotic fleck virus. Ann Appl Biol 108:43-50 